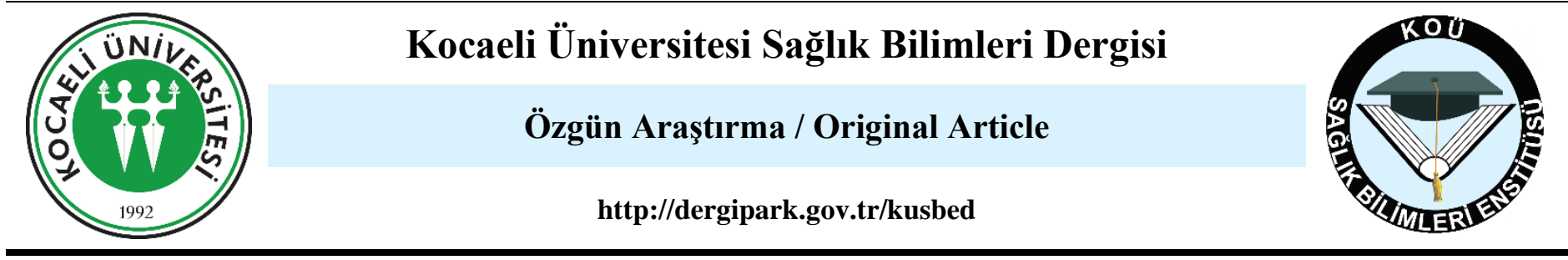

\title{
COMPARISON OF THE ELLIPSOID METHODS AND THE CAVALIERI METHOD, FOR CALCULATING HEMATOMA VOLUME IN COMPUTED TOMOGRAPHY BY NON- SPECIALIST
}

\author{
BILGISAYARLI TOMOGRAFIDE HEMATOM HACMININ UZMAN OLMAYANLAR TARAFINDAN \\ HESAPLANMASI IÇIN ELIPSSOID YÖNTEMLER ILE CAVALIERI YÖNTEMININN KARŞILAŞTIRILMASI
}

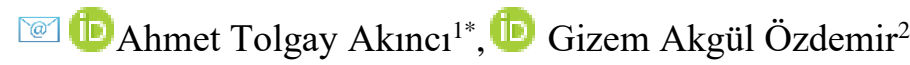

${ }^{1}$ Trakya University, Faculty of Medicine, Department of Neurosurgery, ${ }^{2}$ Faculty of Medicine, Edirne, Turkey

ORCID iD: Ahmet Tolgay Akıncı: 0000-0002-9937-076X; Gizem Akgül Özdemir: 0000-0002-0921-0544

*Sorumlu Yazar / Corresponding Author: Ahmet Tolgay Akınc1, e-posta / e-mail: ahmettolgayakinci@ gmail.com

Geliş Tarihi / Received: 05.05.2020

Kabul Tarihi / Accepted: 08.03.2021

Yayım Tarihi / Published: 29.05 .2021

\begin{abstract}
Objective: Intracerebral haemorrhages account for approximately $20 \%$ of all strokes and have higher morbidity and mortality, nearly $60 \%$ of patients die within a year, and $20 \%$ of the survivors live disabled. The volume of intracerebral haemorrhage has a strong association with the unfavourable outcome; therefore, fast and accurate measurement of the volume is crucial for clinical decision making. This study aimed to compare the ellipsoid methods and the Cavalieri method for calculating intracerebral hematoma volumes by physicians without special education on computed tomography assessment.

Methods: The hematoma volumes in the computed tomography images of 30 consecutive patients were measured via ellipsoid methods and the Cavalieri method. The calculated volumes of hematoma by the four methods were compared statistically.

Results: The median haematoma volumes (interquartile ranges) for 'Cavalieri', 'prolate ellipse (abc)', 'prolate sphere (aac)' and 'sphere (aaa)' methods were 23.2 (27.4), 37.2 (45.8), 22.1 (30.75), and 14.4 (31.87) respectively. A Friedman repeated measures ANOVA test determined that the results of the four methods to evaluate the haematoma volume differ significantly $(p<0.001)$. A Durbin-Conover test demonstrated that the abc method was significantly different from other methods and that no significant difference among other methods was present. A week agreement was found between methods (Kendall's W $=0.3$ ).

Conclusion: Apart from the 'prolate ellipse (abc)' method, which tends to over-calculate the volume, three methods out of four seem feasible to use for physicians without special education on computed tomography assessment.
\end{abstract}

Keywords: Computed Tomography, Intracerebral Haemorrhage Calculation, Volume

$\ddot{\mathbf{O z}}$

Amaç: İntraserebral kanamalar tüm inmelerin yaklaşık \%20'sini oluşturur ve yüksek morbidite ile mortaliteye sahiptir, hastaların yaklaşık \%60'1 bir yıl içinde ölür ve hayatta kalanların ise \%20'si engelli yaşar. İntraserebral kanama hacminin olumsuz sonuç ile güçlü bir ilişkisi vardır; bu nedenle, hacmin hızlı ve doğru bir şekilde ölçülmesi klinik karar verme için çok önemlidir. Bu çalışmada bilgisayarlı tomografi değerlendirmesinde özel eğitim almamış hekimler tarafından intraserebral hematom hacimlerini hesaplamak için elipsoid yöntemlerle Cavalieri yönteminin karşılaştırılması amaçlanmıştır.

Yöntem: Ardışık 30 hastanın bilgisayarlı tomografi görüntülerindeki hematom hacimleri elipsoid yöntemleri ve Cavalieri yöntemi ile ölçüldü. Dört yöntemle hesaplanan hematom hacimleri istatistiksel olarak karşılaştırıldı.

Bulgular: 'Cavalieri', 'yayvan elips (abc)', 'yayvan küre (aac)' ve 'küre (aaa)' yöntemleri için medyan hematom hacimleri (çeyrekler arası aralık) sirasiyla 23,2 (27,4), 37,2 (45,8), 22,1 (30,75) ve 14,4 (31,87) idi. Friedman tekrarlanan ölçümler ANOVA testi, hematom hacmini değerlendirmek için dört yöntemin sonuçlarının önemli ölçüde farklı olduğunu belirledi $(p<0.001)$. Durbin-Conover testi, abc yönteminin diğer yöntemlerden önemli ölçüde farklı olduğunu ve diğer yöntemler arasında anlamlı bir fark olmadığını gösterdi. Yöntemler arasında bir zayıf bir uzlaşma saptandı (Kendall'ın W $=0.3$ ).

Sonuç: Hacmi fazla hesaplama eğiliminde olan 'yayvan elips (abc)' yöntemi hariç tutulursa; bilgisayarlı tomografi değerlendirmesinde özel eğitim almamış doktorlar için dört yöntemden üçü kullanılabilir.

Anahtar Kelimeler: Bilgisayarlı Tomografi, Intraserebral Kanama Hesaplama, Hacim 


\section{Introduction}

Intracerebral haemorrhages (ICH) account for approximately $20 \%$ of all strokes and have higher morbidity and mortality. ${ }^{1,2}$ Nearly $60 \%$ of ICH patients die within a year, and $20 \%$ of the survivors live disabled. ${ }^{1,3}$ Even though ICHs are not only causing harm by their volume effect and their blood content has inflammatory effects; the volume of initial ICH has a strong association with the unfavourable outcome. ${ }^{3-5}$

Fast and accurate measurement of ICH volume is crucial for clinical decision making. Ericson and Hakonsson were the first researchers suggesting the use of an empirical equation of an ellipsoid volume. ${ }^{6}$ In subsequent studies, the ellipsoid equation, known as the 'abc method' was widely used. ${ }^{7,8,5} \mathrm{~A}$ more sophisticated one, the Cavalieri's direct estimation method was also reported to be an effective method for calculating neurosurgically relevant volumes from Computed Tomography (CT) scans. ${ }^{9}$

In the last three-decade, various volume calculation methods have been created and tested with many cadaveric and clinical studies. ${ }^{10-12}$ However, the measurements were commonly made by experts in CT assessment. ${ }^{12}$ Considering the active role in clinicians' clinical decisionmaking without specialised training in volume calculation via $\mathrm{CT}$, the necessity of comparing these methods in their use becomes meaningful.

In this regard, we aimed to compare the ellipsoid methods and the Cavalieri method for calculating intracerebral hematoma volumes by physicians without special education on CT assessment.

\section{Methods}

The study was planned as a single-centre retrospective study. The Ethics Committee of Trakya University approved the study (Decision number: TUTF-BAEK 2020/171). For this kind of studies, written informed consent was not required. The study was carried out at the Trakya University Health Research and Application Centre, Edirne, TURKEY.

\section{Study Population}

Data on patients admitted to our institution with ICH between January 1, 2014, and December 31, 2019, were reviewed retrospectively. CT images of the first consecutive 30 patients with intracerebral haemorrhage were selected. The selected images were taken from the PACS (Picture Archiving and Communication System, Sectra (C2018 PACS IDS7 20.2, Linköping, Sweden).

\section{CT Technique}

CT scans were performed with a 64-slice CT scanner (Aquillon, Toshiba Medical Systems, Tokyo, Japan). Exposure parameters were $120 \mathrm{kV}$ and $125 \mathrm{mAs}$. The section collimation was $0.5 \mathrm{~mm}$, and the images were obtained by axial acquisition without intravenous contrast injection.

\section{Haematoma Volume Calculation Methods}

The parameters used in ellipsoid methods are determined as follows: The widest diameter (b) of the intracerebral hematoma in the axial plane (b), the diameter perpendicular to it (a) and the height in the coronal plane (c) are determined (Figure $1 \mathrm{a} \& \mathrm{~b}$ ). First, and the most straightforward method for volume calculation (aaa) is to assume the haematoma spherical and use the formula:

$$
\text { Volume }=a * a * a *\left(\frac{\pi}{6}\right)
$$

The second method (aac) assumes the haematoma as a prolate sphere and uses the formula:

$$
\text { Volume }=a * a * c *\left(\frac{\pi}{6}\right)
$$

The third and the most sophisticated amongst ellipsoid methods (abc) assumes the haematoma as a prolate ellipse and uses the following formula:

$$
\text { Volume }=a * b * c *\left(\frac{\pi}{6}\right)
$$

For the Cavalieri method, the following steps were taken to calculate the volume of the hematoma: CT images were downloaded from PACS. The values determined in the imaging were taken as the section range. The original images were saved as a ".tiff" image file for each section, including the intracerebral hematoma. Subsequently, using the ImageJ open-source computer program, an equally spaced point grid $(0.1 \mathrm{inch}=0.64516 \mathrm{~cm})$ is superposed on each of the section images (Figure 1c). ${ }^{13}$ The number of points within the boundaries of the hematoma was counted with the program's point counter feature. For the calculation of the volume of the haematoma, the method uses the following formula:

$$
\text { Volume }=\sum_{i=1}^{j} p_{i} * a_{i} * d_{i}
$$

p: number of points, a: area per point $\left(\mathrm{cm}^{2}\right)$, d: section thickness $(\mathrm{cm})$, number of sections from $\mathrm{i}$ to $\mathrm{j}$

All measurements were performed by one of the authors, a physician without specialised training on CT assessment. More than five measurements were not taken on the same day to prevent fatigue. Demographic data of patients such as age and gender and the calculated volumes of hematoma were recorded on a computer database and analysed statistically.

\section{Statistical Analysis}

Shapiro-Wilk test was used to assess the normality of continuous variables. A Friedman test was performed to compare the four methods, and a Durbin-Conover post hoc test was performed for the pairwise comparisons. Kendall's coefficient of concordance was used to examine the agreement between methods. Descriptive statistics for continuous variables were expressed as mean \pm standard deviation or median (interquartile range) based on normality distribution. A p-value of less than 0.05 was considered statistically significant. Statistical analyses were conducted using Jamovi version 1.2 open-source software. ${ }^{14}$

A priori power analysis performed for $\alpha=0.05$, power (1 $\beta)=0.80$ effect size $=0.15$ (medium), and four groups, and the sample size was determined as 80 . Moreover, a post hoc power analysis was performed for global effects with $\alpha=$ 0.05 , power $(1-\beta)=0.82$, effect size $=0.15$ (medium), and a total sample size of 120 , and the post hoc power $(1-\beta)$ was calculated as 0.95 . G*Power software was used for power analysis. ${ }^{15}$

\section{Results}

The mean age was $59.2 \pm 19.5$ years. Eleven patients $(36.7 \%)$ were female, and 19 were male $(63.3 \%)$. Median haematoma volumes (interquartile ranges) for 'Cavalieri', 'abc', 'aac' and 'aaa' methods were 23.2(27.4), 37.2(45.8), 22.1(30.75), and 14.4(31.87) respectively (Table 1). 
Table 1. Descriptives Statistics for Haematoma Volume

\begin{tabular}{|c|c|c|c|c|c|}
\hline & Cavalieri $(\mathrm{n}=30)$ & $\operatorname{abc}(n=30)$ & aac $(n=30)$ & aaa $(n=30)$ & $\begin{array}{c}p- \\
\text { value* }\end{array}$ \\
\hline Median (25th percentile -75 th percentile) & $23.2(10.1-37.5)$ & $37.2(12.4-58.2)$ & $22.1(7.05-37.8)$ & $14.4(4.93-36.8)$ & $<.001$ \\
\hline Skewness & 0.446 & 1.60 & 2.46 & 3.06 & \\
\hline Shapiro-Wilk $p$-value & 0.026 & $<.001$ & $<.001$ & $<.001$ & \\
\hline
\end{tabular}

*Friedman test

Table 2. Pairwise Comparisons of Haematoma Volume Medians (Durbin-Conover)

\begin{tabular}{llll}
\hline Method 1 & Method 2 & Statistic & $p$-value \\
Cavalieri & aaa & 1.881 & 0.063 \\
Cavalieri & aac & 0.235 & 0.815 \\
Cavalieri & abc & 3.997 & $<.001$ \\
aaa & aac & 1.646 & 0.103 \\
aaa & abc & 5.878 & $<.001$ \\
aac & abc & 4.232 & $<.001$ \\
\hline
\end{tabular}
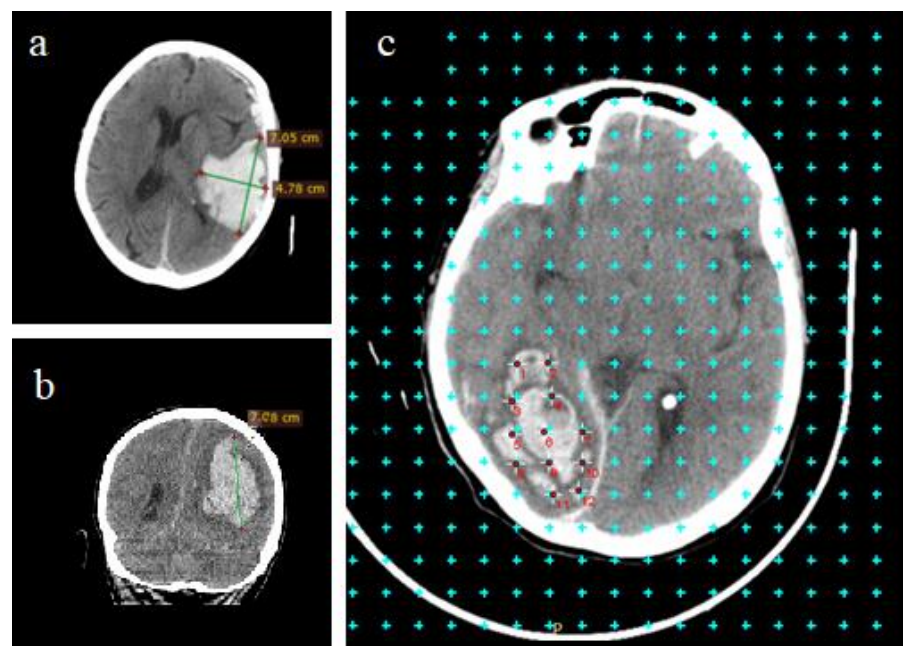

Figure 1. Measurement methods

a. Axial CT image, the measurements for $\mathrm{a}$ and $\mathrm{b}$

b. Coronal plane (reconstructed) CT image, the measurement for $\mathrm{c}$

c. Axial CT image, with a superposed grid $(0.1$ inch $=$ $0.64516 \mathrm{~cm}$ )
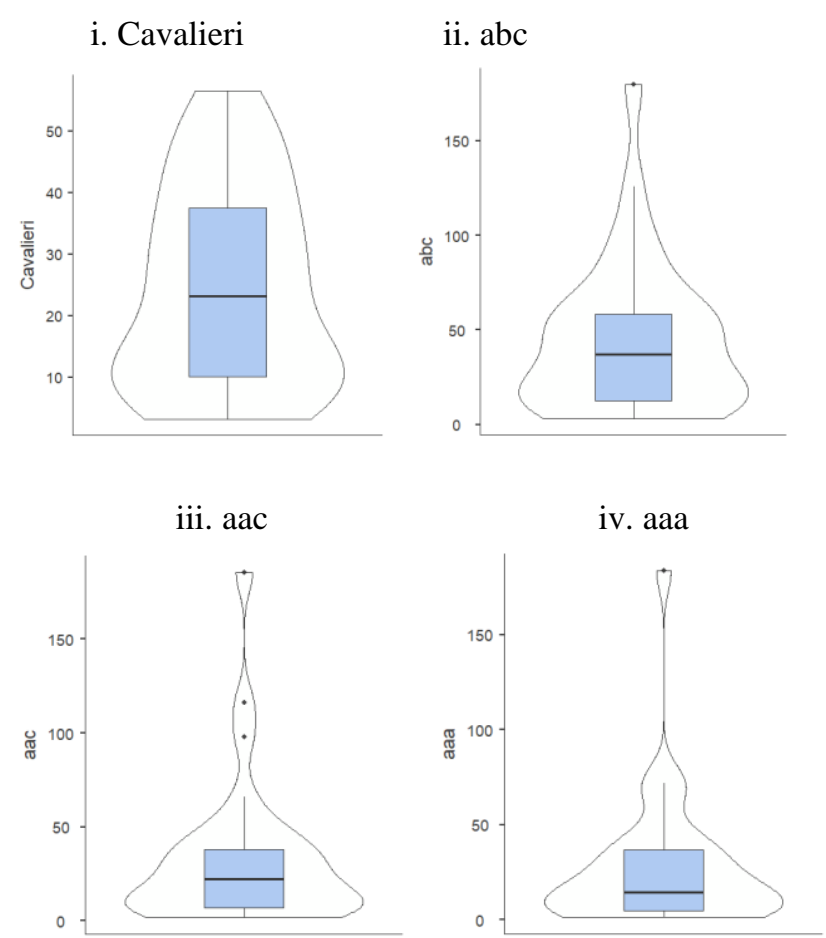

Figure 2. The Distributions of Haematoma Volumes

i. Cavalieri Method, ii. abc Method, iii. aac Method, iv. aaa Method 
The distributions of haematoma volumes were visualised in Figure 2.

The Shapiro-Wilk tests showed that none of the haematoma volume parameters was distributed normally. A Friedman repeated measures ANOVA test determined that the results of the four methods to evaluate the haematoma volume differ significantly $(p<0.001)$. A Durbin-Conover test was performed for the pairwise comparisons, and the results demonstrated that the abc method was significantly different from other methods and that there was no significant difference among other methods (Table 2). Furthermore, a week agreement was found between methods (Kendall's W $=0.3$ ).

\section{Discussion}

ICH puts a severe burden on society as one of the most lethal stroke types. ${ }^{2}$ Hematoma volume is highly correlated with poor results. ${ }^{5}$ There are reports ranging from 20 to 30 $\mathrm{cc}$ as the threshold for surgical intervention. Even though studies have not shown a benefit for surgical evacuation of the haematoma compared to conservative treatment, removal of blood content is accepted to be life-saving for cerebellar haematomas and should theoretically affect neurological recovery positively when indicated and performed for emergency surgery., 3 ,16-18 Moreover, it is reported that selected patients with supratentorial $\mathrm{ICH}$ may benefit from minimally invasive procedures such as endoscopic evacuations. ${ }^{19}$ This kind of surgical interventions is urgent, and its timing has a significant impact on the outcome, correspondingly aggressive initial care is recommended. ${ }^{20}$

There are many proposed methods for ICH volume calculation in the literature. ${ }^{5,6,9-12}$ The reliability and validity of these volumetric and stereological methods have been repeatedly demonstrated. However, in almost all of these studies, measurements were made by experts, sometimes even neuroradiologists. ${ }^{12}$ In our country and in many countries around the world, the management of $\mathrm{ICH}$ patients in practice is carried out by clinicians without expertise in volume calculation in CT. There is a notable difference between ICH mortalities in rural and urban hospitals in the United States. ${ }^{21}$ Therefore, comparing the applications of ICH volume calculation methods by non-specialist clinicians will enable them to demonstrate their usefulness in practice.

In our study, one of the authors, a physician without specialised training on CT assessment, calculated the haematoma volumes by four different methods. As ShapiroWilk tests showed that haematoma volume differences were not distributed normally, and the results were from repeated measures; a Bland-Altman analysis was not performed. ${ }^{22}$ The Friedman test showed that the results of the four methods differed significantly $(p<0.001)$, and pairwise comparisons pointed out that the 'prolate ellipsoid (abc)' method differed significantly. However, there were no significant differences among other methods. Moreover, Kendall's coefficient of concordance showed a weak agreement between methods (Kendall's W=0.3).

The results of this study, in accordance with authors' experiences gained during the study, revealed that the use of volume calculation methods in practice by non-experts might not be as easy, fast and accurate as in theory.

\section{Conclusion}

The 'prolate ellipse (abc)' model seemed to incline to exaggerate the volume of the haematomas. The other three methods seem easy and time saving for physicians without special education on CT evaluation. Further investigation with numerous techniques, utilising more sophisticated computer programs and including larger samples might lead the way for an ideal method.

\section{Limitations}

There are a number of limitations to our study. Despite the higher levels of power evaluated by a priori and post hoc analysis, the number of measurements and especially raters, can be elevated to ensure intra-rater and inter-rater assessments. For more sophisticated and time-consuming measurements, such as the Cavalieri method necessitating two additional computer programs, a more automatised computer-based system of measurement might be a solution.

\section{Acknowledgements}

We thank Selçuk Korkmaz, PhD, for his invaluable statistical guidance and Hilal Akınc1, MSc for her assistance on the proof-reading of the manuscript.

\section{Disclosure}

No funding was received for this research. Authors declare that they have nothing to disclose.

\section{Conflict of Interest}

The authors declare that they have no affiliations with or involvement in any organisation or entity with any financial, or non-financial interest in the subject matter or materials discussed in this manuscript.

\section{Compliance with Ethical Statement}

Given the nature of the study, it was conducted on electronic documents and did not involve any direct human procedures. This article does not contain any studies with human participants performed by any of the authors. The Ethics Committee of Trakya University approved the study (Decision number: TUTF-BAEK 2020/171). For this kind of studies, written informed consent was not required.

\section{Author Contributions}

KG: Design; KG: Project development; KG, LC, CC: Data collection; KG, BA, HD: Analysis; FÖ: Literature search; KG, HD: Manuscript writing; HD, OA: Critical review

\section{References}

1. Rennert RC, Tringale K, Steinberg JA, et al. Surgical management of spontaneous intracerebral hemorrhage: insights from randomized controlled trials. Neurosurg Rev. 2019:1-8. doi:10.1007/s10143-019-01115-2.

2. Smith EE, Shobha N, Dai D, et al. A risk score for in-hospital death in patients admitted with ischemic or hemorrhagic stroke. $J$ Am Heart Assoc. 2013;2(1):e005207. doi:10.1161/JAHA.112.005207.

3. Keep RF, Hua Y, Xi G. Intracerebral haemorrhage: mechanisms of injury and therapeutic targets. Lancet Neurol. 2012;11(8):720-731.

4. Oliveira Manoel AL de, Goffi A, Zampieri FG, et al. The critical care management of spontaneous intracranial hemorrhage: a contemporary review. Crit Care. 2016;20(1):272. doi:10.1186/s13054-016-1432-0.

5. Broderick JP, Brott TG, Duldner JE, Tomsick T, Huster G. Volume of intracerebral hemorrhage. A powerful and easy-to- 
use predictor of 30-day mortality. Stroke. 1993;24(7):987993. doi:10.1161/01.str.24.7.987.

6. Ericson K, Håkansson S. Computed tomography of epidural hematomas. Association with intracranial lesions and clinical correlation. Acta Radiol Diagn (Stockh). 1981;22(5):513-519. doi:10.1177/028418518102200501.

7. Petersen OF, Espersen JO. Extradural hematomas: measurement of size by volume summation on CT scanning. Neuroradiology.

1984;26(5):363-367. doi:10.1007/bf00327488.

8. Kwak R, Kadoya S, Suzuki T. Factors affecting the prognosis in thalamic hemorrhage. Stroke. 1983;14(4):493-500. doi:10.1161/01.str.14.4.493.

9. Clatterbuck RE, Sipos EP. The Efficient Calculation of Neurosurgically Relevant Volumes from Computed Tomographic Scans Using Cavalieri's Direct Estimator. Neurosurgery. 1997;40(2):339-343. doi:10.1097/0006123199702000-00019.

10. Cuce F, Tulum G, Dandin Ö, Ergin T, Karadas Ö, Osman O. A New Practical Method for Intracerebral Hematoma Volume Calculation and its Comparison to the simple $\mathrm{ABC} / 2$ method. Turk Neurosurg. 2019. doi:10.5137/1019-5149.JTN.2599619.2 .

11. Divani AA, Majidi S, Luo X, et al. The ABCs of accurate volumetric measurement of cerebral hematoma. Stroke. 2011;42(6):1569-1574. doi:10.1161/STROKEAHA.110.607861.

12. Stocchetti N, Croci M, Spagnoli D, Gilardoni F, Resta F, Colombo A. Mass volume measurement in severe head injury: accuracy and feasibility of two pragmatic methods. J Neurol Neurosurg Psychiatry. 2000;68(1):14-17. doi:10.1136/jnnp.68.1.14.

13. ImageJ. https://imagej.nih.gov/ij/. Updated September 14, 2019. Accessed February 4, 2020.

14. Jamovi - Stats. Open. Now. https://www.jamovi.org/. Updated February 4, 2020. Accessed February 4, 2020.

15. Faul F, Erdfelder E, Lang A-G, Buchner A. G*Power 3: a flexible statistical power analysis program for the social, behavioral, and biomedical sciences. Behavior Research Methods. 2007;39(2):175-191. doi:10.3758/BF03193146.

16. Wang G, Wang L, Sun X-G, Tang J. Haematoma scavenging in intracerebral haemorrhage: from mechanisms to the clinic. J Cell Mol Med. 2018;22(2):768-777. doi:10.1111/jcmm.13441.

17. Thabet AM, Kottapally M, Hemphill JC. Management of intracerebral hemorrhage. Handb Clin Neurol. 2017;140:177194. doi:10.1016/B978-0-444-63600-3.00011-8.

18. Mendelow AD, Gregson BA, Fernandes HM, et al. Early surgery versus initial conservative treatment in patients with spontaneous supratentorial intracerebral haematomas in the International Surgical Trial in Intracerebral Haemorrhage (STICH): a randomised trial. Lancet. 2005;365(9457):387397. doi:10.1016/S0140-6736(05)17826-X.

19. Scaggiante J, Zhang X, Mocco J, Kellner CP. Minimally Invasive Surgery for Intracerebral Hemorrhage. Stroke. 2018;49(11):2612-2620. doi:10.1161/STROKEAHA.118.020688.

20. Andrews CM, Jauch EC, Hemphill JC, Smith WS, Weingart SD. Emergency neurological life support: intracerebral hemorrhage. Neurocrit Care. 2012;17 Suppl 1:S37-46. doi:10.1007/s12028-012-9757-2.

21. Faigle R. Location, Location, Location: The Rural-Urban Divide in Intracerebral Hemorrhage Mortality. Neurocrit Care. 2020. doi:10.1007/s12028-020-00952-0.

22. Doğan NÖ. Bland-Altman analysis: A paradigm to understand correlation and agreement. Turk J Emerg Med. 2018;18(4):139-141. doi:10.1016/j.tjem.2018.09.001. 